\title{
Efficacy of abatacept in juvenile idiopathic arthritis related uveitis
}

\author{
LA Katargina ${ }^{1 *}$, EV Denisova' ${ }^{1}$ AV Starikova', NV Lubimova', IP Nikishina ${ }^{2}$ \\ From 18th Pediatric Rheumatology European Society (PReS) Congress \\ Bruges, Belgium. 14-18 September 2011
}

\section{Background}

Despite various immunosuppressive agents, juvenile idiopathic arthritis (JIA) related uveitis often take a serious course that leads to sight threatening complications.

\section{Aim}

To evaluate efficacy of Abatacept in combined treatment of JIA related uveitis.

\section{Methods}

10 children aged $4-12$ years with anterior uveitis associated with JIA were treated by Abatacept in standard infusions pattern and doses. Indication for using Abataceptwas ineffectiveness of standard therapy of arthritis and/or uveitis. 6 patients were suffering from polyarticular variants, 4 - oligoarticular JIA. Abatacept was combined with Methotrexate in 9, Sulfasalazin in 1 and lowdose steroids in 4 children. 3 patients were switched to Abatacept from Infliximab due to non-efficacy, 7 received abatacept as a first line biologic. 9 patients had bilateral eye involvement. At the administration of Abatacept severe inflammation was seen in 1, moderate in 7 , mild in 2 of the cases. Follow up period ranged from 3 to 11 month (mean 7.6). The main outcome measure was the degree of inflammation.

\section{Results}

Remission of uveitis in current treatment was achieved in $6(60 \%)$, improvement in the degree of inflammation in $2(20 \%)$ of the cases. The initial response was seen after the $2^{\text {nd }}-4^{\text {th }}$ injection. From patients switched from Infliximab to Abatacept 1 achieved remission of uveitis, 1 improved, 1 remained stable. Patients with remission of uveitis diminished or discontinued topical

${ }^{1}$ Helmholtz Research Institute of Eye Diseases, Moscow, Russia

Full list of author information is available at the end of the article medications. No ocular or systemic adverse effects were observed. Glaucoma or cataract surgery was uncomplicated in all 4 cases.

\section{Conclusions}

Administration of Abatacept was effective in $80 \%$ of children with JIA related uveitis. Further investigations are required to define clear indications for this treatment in severe uveitis.

\section{Author details}

${ }^{1}$ Helmholtz Research Institute of Eye Diseases, Moscow, Russia. ${ }^{2}$ Scientific Research Institute of Rheumatology of Russian Academy of Medical Sciences, Moscow, Russia.

Published: 14 September 2011

\section{doi:10.1186/1546-0096-9-S1-P100}

Cite this article as: Katargina et al:: Efficacy of abatacept in juvenile

idiopathic arthritis related uveitis. Pediatric Rheumatology 2011 9(Suppl 1): P100.

Submit your next manuscript to BioMed Central and take full advantage of:

- Convenient online submission

- Thorough peer review

- No space constraints or color figure charges

- Immediate publication on acceptance

- Inclusion in PubMed, CAS, Scopus and Google Scholar

- Research which is freely available for redistribution

\section{Ciomed Central}

